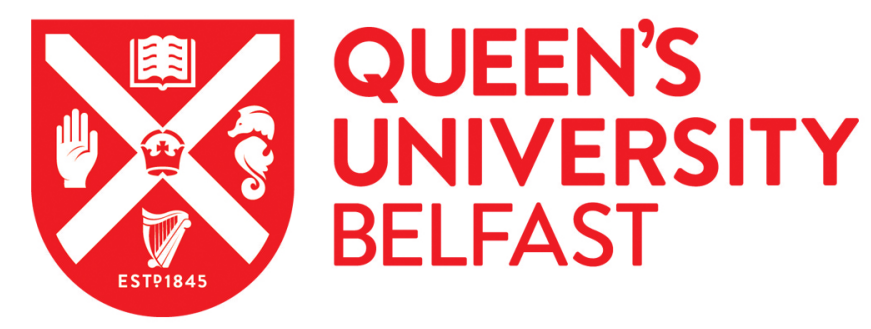

\title{
Reconciling Children's Policy and Children's Rights: Barriers to Effective Government Delivery
}

Byrne, B., \& Lundy, L. (2015). Reconciling Children's Policy and Children's Rights: Barriers to Effective Government Delivery. Children and Society, 29(4), 266-276. https://doi.org/10.1111/chso.12045

Published in:

Children and Society

Document Version:

Peer reviewed version

Queen's University Belfast - Research Portal:

Link to publication record in Queen's University Belfast Research Portal

Publisher rights

(c) 2013 John Wiley \& Sons

\section{General rights}

Copyright for the publications made accessible via the Queen's University Belfast Research Portal is retained by the author(s) and / or other copyright owners and it is a condition of accessing these publications that users recognise and abide by the legal requirements associated with these rights.

Take down policy

The Research Portal is Queen's institutional repository that provides access to Queen's research output. Every effort has been made to ensure that content in the Research Portal does not infringe any person's rights, or applicable UK laws. If you discover content in the Research Portal that you believe breaches copyright or violates any law, please contact openaccess@qub.ac.uk. 


\title{
Reconciling Children's Policy and Children's Rights: \\ Barriers to Effective Government Delivery
}

\begin{abstract}
Countries which have ratified the United Nations Convention on the Rights of the Child, have committed to implementing its principles in law and policy. This article explores the challenges for securing children's rights through policy, drawing on a research project conducted for the Northern Ireland Commissioner for Children and Young People which sought to identify barriers to effective government delivery for children and young people from the perspective of key stakeholders. The research concluded that, whilst some barriers (such as delay and availability of data) are not child-specific, they can be accentuated when children and young people are the main focus of policy development and more so when seeking to adopt a child rights-compliant approach to policy development and implementation.
\end{abstract}

\section{Introduction}

From education, health and social care, to play and leisure, the justice system and beyond, almost every aspect of children and young people's lives has been subject to recent and on-going policy scrutiny, with 'new' areas emerging on a regular basis. Examples include the Improving Services for Looked after Children policy in England, the Early Years Framework in Scotland, the Child Poverty Strategy in Wales, and the current policy debates surrounding Shared Education in Northern Ireland. Parallel to 
these developments is the acceptance among signatory states, including the United Kingdom, of the United Nations Convention on the Rights of the Child ('the CRC'), as an important part of the broader policy context. States Parties commit to implementing children's rights by developing, implementing and integrating its obligations under the CRC into appropriate policies and laws (UN 2003, para 9). Each of the four jurisdictions of the UK has recognised the CRC as a key aspect of its plans for children (DCSF 2008; Scottish Government 2009; OFMDFM 2006; Welsh Assembly Government 2009). As such, the CRC should have a core role to play in informing and shaping policy discourse for children and young people.

The extent to which government takes its obligations seriously can be compounded by the inherent complexities of policymaking. The transmutation of any policy from formulation stage with its signalled intentions, commitments and objectives, to its subsequent implementation, and from the latter to the achievement of concrete outcomes and their evaluation is fraught with difficulties. Conflicting agendas, varying mandates, resource implications and political will are just some factors that can impinge upon the process of 'translating policy into action' (Barratt 2004, p.251). Policy processes are value laden, having both implicit and explicit things to say about those overseeing the process, the subject matter, the characteristics of the targeted population group, and about the value that is accorded to rights discourse. The Committee on the Rights of the Child, reflecting upon some of these issues, has suggested that the ways in which policy is developed and implemented is reflective of the place of the child in society and the political priority accorded to children and their rights (UN 2003, para 10).

This paper explores some of the challenges for securing children's rights through policy processes, focusing on the implications of these for children and young people. It draws upon findings in a recent research project carried out for the Northern Ireland 
Commissioner for Children and Young People (NICCY) which explored the key barriers to effective government delivery for children and young people. The range of barriers identified prompted consideration of the extent to which these were child-specific or childrights specific in nature or a common, albeit undesirable, feature of policymaking irrespective of the targeted group. The aim of the article is to assess the extent to which the identified barriers to policy development impact on children and young people to a greater, lesser or comparable extent than the population more generally, particularly when a child rights-based approach is a key objective. In particular, it explores the implications of, and difficulties associated with, children's rights-based approaches and discourse in this context. The article concludes by reflecting on the implications of policy processes for children and young people and suggests that whilst some barriers are representative of the complexities associated with policy processes generally, they can be exacerbated when children and young people are the main focus and become more difficult still when the intention is to adopt a CRC-compliant approach to policy development and implementation.

\section{The Project}

The research team was commissioned by NICCY to analyse the key structural barriers to effective government delivery for children in Northern Ireland and to develop a set of recommendations on the ways in which the identified barriers could be overcome. The rationale for the project arose out of the fact that between 2007 and 2011 in Northern Ireland, a number of significant government policies and strategies relating to children and young people have been in various stages of development and implementation including: a Ten Year Children and Young People's Strategy and associated action plans (OFMDFM 2006), a Play Strategy and Implementation Plan (OFMDFM 2009), a Review of Mental Health and Learning Disability (Bamford) Plan (DHSSPS 2008), a Family 
Matters Strategy (DHSSPS 2009), a Care Matters Strategy (DHSSPS 2009), and a draft Early Years Strategy (DE 2010).

It is no coincidence that the upsurge in the sheer number of policy developments occurred immediately following the restoration of devolution in Northern Ireland in May 2007 (Hogan and Gray 2012). A similar raft of policy change has been occurring in all regions of the UK; however the context in which such change has been taking place in Northern Ireland is distinct. The region's capacity for policy-making and self-government has been constrained by wider constitutional questions and an ongoing power relay between Direct Rule by Westminster and devolved government. Transition to a postconflict society, in the wake of over thirty years of violence, has been accompanied by an enhanced human rights dimension as illustrated by the establishment of a Human Rights Commission and commitment to a Northern Ireland Bill of Rights alongside other equality provisions emanating from the Belfast or 'Good Friday' Agreement of 1998 and enacted by the Northern Ireland Act 1998. As such, human rights have had a significant role to play in facilitating transition to a 'new' Northern Ireland.

Article 4 of the CRC obliges States Parties to take 'all appropriate legislative, administrative and other measures for implementation'. The Committee has produced detailed guidance on the structures that must be put in place to ensure that the substantive rights and provisions are effectively and fully implemented (UN 2003). For example, it has stated that effective implementation of the CRC requires: a comprehensive and continuous review of all domestic legislation and administrative guidance against the principles and standards of the Convention; a unifying, comprehensive and rights based national strategy; visible cross-sectoral coordination; a continuous process of child impact assessment; children's rights budgeting; disaggregated data and research; training and capacity building for all those involved in 
implementing the CRC; and engagement with children and young people and other key stakeholders. The types of measures that should be employed to secure rights-compliant policy review are thus wide-ranging in scope and States Parties have documented a wide variety of legislative, social and other measures with different degrees of success when it comes to the implementation of these. These measures range from full incorporation of the CRC into domestic law in countries such as Belgium, Norway and Spain; integration of CRC principles in domestic law (for example the best interests principle in areas such as juvenile justice (Ireland) and immigration (Norway)); child impact assessment in Sweden and Belgium; child budgeting in South Africa; the development of data collection projects such as the Growing up in Ireland study and Australia's Child Development Index; and national strategies and action plans (Lundy, Kilkelly, Byrne and Kang 2012).

With this in mind, the study had three key strands. First, the project team developed a set of qualitative indicators specific to the implementation of the CRC in policy to provide an overall frame for the project. The second stage of the project consisted of a review of key government strategies, policies and action plans of relevance to children and young people in Northern Ireland, including those mentioned above, using the developed indicators as benchmarks. Finally, sixteen semi-structured interviews were carried out with representatives from voluntary agencies, statutory agencies, government departments (including policymakers), and Members of the Northern Ireland Assembly (MLAs). What follows is an account of the main barriers to government delivery for children and young people that emerged from the study in terms of: delay in policy development and implementation; lack of coordination and joined up government; insufficient data; limited engagement with children and young people; and limited commitment to children's rights. 


\section{Delays in Policy Development and Implementation}

Delays can be a common, albeit unwanted, characteristic of policymaking in a context of competing interests and priorities. The study highlighted significant time lags between between the planning and implementation stages of strategies or policies relevant to children and young people. There was concern at the length of time taken from initial conception to the approval and issue of the final document and subsequent plans and implementation. For example, a Task Force on Speech and Language Therapy was established by the Northern Ireland Minister for Health in 2006. However, an associated action plan was not completed and approved until March 2011. A breakdown of the timeframe for each strategy and policy included in the study is provided in Table 1: 


\begin{tabular}{|l|l|}
\hline Policy/Strategy & $\begin{array}{l}\text { Average timescale from } \\
\text { initial conception to final } \\
\text { document }\end{array}$ \\
\hline Every School a Good School & $2-3$ years \\
\hline Care Matters & 3 years \\
\hline Play and Leisure Policy & 4 years \\
\hline Families Matter & 5 years \\
\hline Children and Young People's Strategy & 5 years \\
\hline The Way Forward for Special Educational & 6 years + \\
\hline Needs & \\
\hline Early Years Strategy & 6 years + \\
\hline Speech, Language and Communication & 6 years \\
\hline Therapy Action Plan & 9 years \\
\hline Dafeguarding Board for NI & \\
\hline
\end{tabular}

As can be seen, the timeframe for relevant policies and strategies varies significantly from $2 / 3$ years to a somewhat worrying 9 years, especially given that the focus of the 
latter (safeguarding) was an issue of general and immediate concern to the public and politicians alike. In some instances, existing action plans have become outdated with new updated action plans yet to be produced. There were also other issues: the Care Matters Strategy, which focuses on the needs of young people in care, was not redrafted following the consultation process, but endorsed by the Northern Ireland Executive in its draft pre-consultation form. In relation to Families Matter and Delivering the Bamford Vision, resultant action plans did not form part of the consultation process at all. The reasons for and implications of such prolonged development stages were highlighted extensively in conversations with stakeholders. High levels of staff turnover and the subsequent loss of expertise that had been previously taken time to build up is one such example:

"Somebody has maybe taken a strategy so far and done a lot of work on it and leaves.... Someone was seconded into the department to develop the Early Years Strategy and had produced a draft but then had gone back out of the department again after the secondment was completed and somebody else came in and it was all rewritten." (Statutory agency representative)

Of particular pertinence was the complex and immature nature of the current Northern Ireland political system. Long-ranging timescales have been a particular feature of the policy landscape in Northern Ireland in the face of longstanding political difficulties and the subsequent establishment of a five-party coalition post-2007 (Gray and Birrell, 2012). This unique scenario has brought with it a whole new set of considerations, including the ongoing need for cross-party agreement. The latter has been viewed as the main contributory factor for the 'near policy impasse' that has prevailed with the Northern Ireland Executive failing to reach agreement on a number of major social policy issues (Gray and Birrell, 2012). This was emphasised by policymakers who put the reason for 
delays down to the subsequent backlog the need for cross-party agreement created in gaining approval of policy proposals:

"The number of departments, the fragmentation of delivery... the large number of MLAs and the fact that our Executive is not a single party or not even two parties in coalition. It can be difficult to get agreement and it can take a very long time." (Policymaker).

This 'near impasse' has clearly extended to issues relating to children and young people. There is a danger that such delays will have a disproportionate impact on children and young people due primarily to the fact that policies for this group tend to have implications for long term outcomes. Longer than anticipated time lags in areas of education, health and early intervention, impact on children at a crucial point in the life course, with particular consequences for those from marginalised groups (UN 2003; 2005).

\section{Lack of Coordination and Joined-up Government}

A lack of coordination and 'joined-up working' across government departments emerged as the primary barrier to effective government delivery for children and young people. This is in spite of the consistent emphasis that has been placed on cross-sectoral coordination by the Committee (UN 2003, para 37-39). The latter emphasis is reflective of the reality that children's lives do not fall neatly into the realms of single government departments. While there was some evidence of good practice of collaboration at intraagency level, this was not always replicated at central government level. Joined-up working between departments was perceived to be based primarily upon goodwill and good working relationships between individuals in respective departments, resulting in inconsistency of practice. Policymakers in particular highlighted the importance of knowing whom to approach in respective departments, something which was made all 
the more difficult in the context of on-going departmental restructuring and reorganisation. These difficulties are due, in part, to the fact that the Office of the First Minister and deputy First Minister (OFMdFM), whose role it is to contribute to and oversee the co-ordination of Executive policies, is not a statutory body; nor does it have a statutory duty or the power to enforce collaboration between Government departments. The practical difficulties in coordinating policy agendas were described by one policymaker as follows:

"I've no difficulty developing policy in my department; I can do that without any great problem. But children's lives obviously don't fall into the categories of Government departments and it's a lot more difficult to draw a policy with [other departments]... and yet clearly to improve outcomes from children, you need to have a policy agenda which is joined up across departments."

The problems associated with joined-up working are not ameliorated by very diverse ministerial portfolios from across the Northern Ireland political spectrum. As one NGO representative put it: “They guard their own portfolio very closely and aren't willing to go outside of that in terms of sharing resources or joined-up policy agendas." The fragmented approach to strategy and policy development has been highlighted as a key failure of a number of strategies. For example, there was concern that the draft Early Years Strategy failed to address the divide between early years education and childcare, which comes under the remit of two different departments. Similar concerns have been expressed in respect of the Play and Leisure implementation plan and the Special Educational Needs proposals wherein responsibility for the successful delivery of policy objectives is dependent upon effective and sustained collaborative working across departments. 
A solution to these on-going issues was perceived to lie in the establishment of a statutory duty to cooperate. Representations submitted to Government on this issue have not, to date, succeeded despite the precedent set for such an approach under the Children Act 2004 in England and Wales (Hudson 2005). The Green Party for Northern Ireland has developed proposals for a Private Members Bill on a statutory duty to cooperate (Green Party NI 2012). The key objective of the bill is to introduce a legal duty on the Northern Ireland Executive to collaborate in the achievement of outcomes for children and young people and for relevant Government departments and agencies to collaborate in the planning, commissioning and delivering of children's services. It remains to be seen whether and to what extent these proposals will attract support from other political parties in the Northern Ireland Assembly.

Failure of government departments or agencies to work together effectively can have exceptionally tragic consequences for children and young people and can also contribute to poor social, educational and health outcomes, for example, with respect to children in care, disabled children, children in the early years, and young people at times of transition (Greco and Sloper, 2004; Kaehne and Beyer, 2009). Heavy reliance on goodwill and the insistence in compartmentalising children's lives can lead to a form of implementation that is disjointed and fragmented in practice. It also fails to give due consideration to the Committee's observation that child development is a holistic concept, embracing the whole Convention (UN 2006, para 10). While the importance of joined-up working is widely recognised at policy level, there is little evidence of this occurring in daily practice.

\section{Insufficient Data}


Determination of the state of play at any given point in time; how well a policy is working; its actual impact on targeted group(s); and identification of policy gaps; underpins the need for good quality data systems. It is also a crucial tool in monitoring national implementation of the CRC. The Committee has said that data on children must be comprehensive, reliable and sufficiently disaggregated to enable the identification of discrimination and/or disparities in the realisation of rights across the State Party (UN 2003, para 48). In practice however, the study identified clear concerns from NGOs at the lack of data on many aspects of children and young people's lives in Northern Ireland and that, where data had been collected, it was not sufficiently disaggregated to facilitate the identification of discrimination or to enable meaningful assessment of progress against strategies and policies. This is a far-reaching issue; international statistics on children tend to use aggregated national data which ranks countries according to their performance on particular outcomes (Ennew, 2011). As such, "children... tend to be a statistically undifferentiated category" (Ennew 2011, 152) in a way that is different from adults. Whilst differentiation of adult-based data on the grounds of, for example, gender, religion, and ethnicity, is increasingly common, disaggregation on these grounds among children is less so, and can be more complex to achieve. There is also a tendency for data to focus on key child development and well-being indicators rather than the full range of children's rights (Lundy, Kilkelly, Byrne and Kang 2012).

Nevertheless, the importance of good data was recognised across NGOs and government representatives, with one policymaker stating that 'trying to implement policy without data is like trying to go to war without a map.' Information is still lacking in relation to vulnerable and marginalised groups, including Traveller children, refugee children, children in poverty, disabled children and looked-after children. These areas were perceived as being 'difficult' to measure with one policymaker stating that they tended 'not to get involved in research where there are some very difficult issues like child abuse 
or domestic violence.' Yet these groups of children are more likely to experience violations of their rights. As Ennew (2011) demonstrates, sensitive topics such as sexual exploitation and abuse, as well as the lives of particularly vulnerable groups of children, can be difficult to access and measure, and subject to the control of adult gatekeepers, with the result that data on these remains comparatively scant. The lack of comprehensive data that is qualitative and quantitative, child-centred and sufficiently disaggregated raises concerns on the extent to which the impact of strategies and policies can be accurately measured and government delivery for children fully assessed.

\section{Limited engagement with children and young people in policy development and implementation}

It is only relatively recently that children have entered into policy discourse as 'policy actors' (Arnott, 2006). The Committee has emphasised that the views of children should 'be considered in policymaking' (UN 2009, para 12) in the context of Article 12 of the $\mathrm{CRC}$ which provides all children with the right to express their views in matters affecting them and for those views to be given due weight in accordance with the age and maturity of the child. The Committee has also identified Article 13 (the right to freedom of expression) and Article 17 (access to information) as crucial prerequisites for the effective exercise of the right to be heard. The trend towards involving children and young people in consultation processes in Northern Ireland was clear to see from the study. A key indicator of success was the extent to which 'The Participation Network', had become the first point of call for policymakers. The Participation Network is a network supported by the Northern Ireland Office of the First Minister and deputy First Minister (OFMDFM) and helps the Public Sector to engage effectively with children and young people in the 
Reconciling Children's Policy and Children's Rights

development and review of policy and services. The impact of children's views on policymakers was evident:

'Consultation with children and young people tends to... be very direct, extremely forceful and has a real quality to it that you don't get from consultees who are at system level... It puts policy developers quite healthily in their place' (Policymaker)

Meaningful and consistent engagement can prove challenging in a fragmented policy environment

. Children and young people involved in policymaking processes may not always be representative of local or targeted childhood populations and such processes do not always lead to tangible policy outcomes (Tisdall and Davis, 2004). The move towards participatory forms of governance has not been without critique. Whilst welcomed in theory, in practice this has been accompanied by concern as to the meaningfulness of involvement in consultation processes (Tisdall 2008; Sinclair 2004). These concerns relate to the amount of information that is provided in consultation documents, the length of documents, and the way in which comments from consultees are received. The study highlighted that it was not always clear what impact children's views had on the final strategy and there was little evidence of particular examples where views had informed a final policy. For instance, children's views on the second Children and Young People's Action Plan (2008-2011) were not sought until August 2009 once the Plan had already been developed and issued to departments. There was also evidence that children and young people were not always consulted at the same time as adults. For example, the children's version of the Care Matters Strategy was not produced until 2 June 2007, a short time before the initial consultation period was due to end (15 June 2007). The latter theme is concerning, appearing to reflect value judgments, or a lack of awareness, on children and young people's capacity to express views and contribute to policymaking 
processes. Whilst policies and consultation documents are generally publicly available to the adult population, through websites for example, children and young people are often dependent on whether or not child friendly versions are produced, and the ways in which these are made available by adult gatekeepers. A documentary analysis of the policies included in the study indicated that, in the majority of cases, a children and young person's version of either the consultation or final document were not produced and/or available. One policymaker was of the view that consultation events with children, where they occurred, had become a 'tick box' exercise and found that directly involving young people through meetings had a much more significant impact on policy development:

'[l]n those meetings I got to hear probably some of the most salient pieces of information about policymaking that I needed to...it wasn't like a game or an exercise that we did in a facilitated way, it was a proper meeting'

Such meetings remain rare. These issues raise questions on the degree to which engagement with children in policy development has been meaningful. While there is an increasing trend and recognition of seeking children's views, assessing the long term impact such views had on government delivery for children is much more problematic.

\section{Limited Commitment to Children's Rights}

More broadly there was a recurring theme around the level of commitment to children's rights. In spite of the UK ratification, the Committee has expressed concern 'that the Convention is not regularly used as a framework for the development of strategies throughout the State party.' (UN 2008, para 14). The degree of consistency with which the issue of children's rights was, firstly, addressed, and secondly, put into practice, 
varied; not just between Government departments but between strategies and policies irrespective of origin. Lack of a children's rights-based approach to the development of policies was a core concern expressed by NGOs. Issues raised included concern at the absence of any reference to children's rights at all; failure of departments to engage with the cross-cutting principles of the CRC and/or with any or all relevant substantive children's rights standards; and the absence of an underlying child rights framework in policy development more generally. Indeed, the draft Children and Young People's Strategy (October 2003) was initially set as Northern Ireland's 'implementation plan for the Convention'. However, the final strategy replaced that approach with one that will instead help drive Northern Ireland "towards a culture which respects and progresses the rights of the child." (OFMDFM 2006, 13).

It is interesting to note that some consultation documents, such as the Families Matter Strategy did not contain any reference to children's rights initially. References were included in the final document following the consultation process. There are examples of good practice, such as the recent assessment of compliance of the draft Early Years Strategy with the CRC. While not complete; Article 2, the right to non-discrimination and a guiding principle of the CRC was omitted; it was the first time such an exercise had been undertaken in policy development and could be built upon. The extent to which a children's rights-based approach was considered or applied to policy development was perceived as being very much down to the commitment of individuals within departments and/or ministerial views on children's rights. The contested and political nature of 'rights' in Northern Ireland was a particular feature of discussions:

'Sadly, the issue for us is that we have some people in government who ... very often turn the debate to children versus parents' rights... But it is a contentious issue; rights in 
general in Northern Ireland let alone children's rights, so very often people tend not to use the word or shy away from it' (Statutory Agency representative).

The priority accorded to children's rights has not been assisted by the drawn out Bill of Rights process in Northern Ireland which did not propose any new rights for children (NIO 2009, 62). This process emerged as a component of the peace process independently of, and separate to, human rights discussions across the UK. The contested nature of 'rights' discourse in Northern Ireland has had particular implications for children and young people, perpetuating a conservative and predominantly protectionist approach to children at policy level. As a result, children and young people have been viewed in policy processes as objects of concern with active resistance to their positioning as rights-holders. Nevertheless, there was evidence of growing recognition of the importance of the CRC among some MLAs. For example, one MLA said: "I would like to see more around the children's rights based framework because I think a children's rights framework, if it was common parlance in Government, we would start to see the delivery of a lot more for children and young people."

Linked to this are levels of training and awareness on children's rights across Government. This is grounded in Article 42 of the CRC which obliges States Parties to make its principles and provisions widely known. While civil servants in Northern Ireland are required to attend mandatory training on human rights, equality and diversity, systematic training on the $\mathrm{CRC}$ is not compulsory or provided routinely to those who are directly involved in developing or implementing a strategy or policy. As such, there is a general lack of understanding of the CRC and its implications for the development and subsequent implementation of policies. Facilitating awareness, commitment, and ultimately, operationalization, of children's rights is an ongoing endeavour, particularly where there is already resistance to rights discourse. 


\section{Conclusions}

Policy processes can be complex and fraught with difficulties irrespective of the policy area or point in the life course that is the focus of proposed reform. Competing priorities, transforming strategic visions into specific and measurable outcomes, and securing adequate resources are just some of the factors that come to the fore in attempts to address even the most pressing policy issues. Facilitating effective policy development and implementation becomes ever more challenging in the face of budgetary cuts and political challenges. This article has highlighted a range of those challenges and the ways in which they have impacted on policy development and implementation with respect to children and young people.

Not all of the challenges identified in the research are wholly child specific. We would suggest, however, that these challenges may be exacerbated when children and young people's lives are the subject of policy development and implementation, with potentially negative implications for both short and long term outcomes and for subsequent stages of the life course. These concerns are further accentuated when child rights discourse is added into the mix. Whilst children's rights are regularly used as a strong lobbying tool by NGOs and as a rallying point for politicians, this can stop short of full or effective implementation when its perceived realities are brought to bear. The intersection between childhood and rights is an added complexity with the elevation of children and young people to a 'rights status' appearing to generate fears of 'new' ways of being and doing in spite of the international obligations that already exist.

In conclusion, if children and young people are to benefit fully and expediently from policy initiatives, there needs to be explicit recognition of the particularities of the policy process 
for this group and ways in which policy challenges can impact disproportionately. The obligations under the CRC are not meant to be taken lightly, yet remain largely confined to the margins of policymaking. A child rights compliant approach to policy development and implementation is not unachievable; many countries have successfully adopted a range of models to this end (Lundy, Kilkelly, Byrne and Kang 2012). A core underpinning to the myriad of approaches that exist in this regard is, however, political will. The importance of this can be seen through rights-based legislative developments such as the Rights of Children and Young Persons (Wales) Measure (2011) and the Children and Young People Bill in Scotland. Both have emerged, not just as a result of sustained lobbying from respective children's sectors, but reciprocal engagement by decisionmakers. Effective implementation of child rights does not exist in a vacuum but requires active facilitation by state actors. Such commitment can be dependent, not only on willingness to listen, accept and 'follow through', but upon the costs and practicalities of implementation and availability of resources. In some cases political will may already exist, or can be generated through sustained dialogue with stakeholders; in other instances enforced political will may be required through, for example, incorporation of the CRC into national law. There is evidence to suggest that giving legal status to the CRC in some form, combined with effective monitoring and enforcement mechanisms can provide the required impetus to better protect children's rights (Lundy, Kilkelly, Byrne and Kang 2012). Sustained investment in training is also required to kick-start an awareness-raising process in a way that will allow a children's rights culture to definitively and substantively emerge. This has particular connotations for those who are responsible for policy operationalization. Recognition of the legitimacy and utility of children's rights by policymakers is a crucial stepping stone to the development of an environment in which children's rights can be effectively realized. This is not to underestimate the difficulties that may still remain, but is recognition of the importance 
Reconciling Children's Policy and Children's Rights

of a child rights sensitive context which allows substantive engagement with the issues to take place and solutions to be found. 


\section{References}

Arnott, M. (2006) Public Policy, Governance and Participation in the UK: A Space for Children? International Journal of Children's Rights, 16, pp.355-367.

Barratt, S. (2004) Implementation Studies: Time for a revival? Personal reflections on 20 years of Implementation Studies, Public Administration, 82, pp 249-262.

Department for Children, Schools and Families (2009) United Nations Convention on the Rights of the Child: Priorities for Action, Nottingham: DCSF.

Department of Education (2009) Every School a Good School: The Way Forward for Special Educational Needs Consultation, Bangor: DE.

Department of Education (2010) Early Years 0-6 Strategy: Consultation paper, Bangor: DE.

Department of Health, Social Services and Public Safety (2007) Families Matter Strategy: Supporting Families in Northern Ireland, Belfast: DHSSPS.

Department of Health, Social Services and Public Safety (2009) Care Matters: A Bridge to a Better Future, Belfast: DHSSPS.

Department of Health, Social Services and Public Safety (2009) Delivering the Bamford Vision Action Plan 2009-2011, Belfast: DHSSPS. 
Ennew, J. (2011) Has Research Improved the Human Rights of Children? Or have the Information Needs of the CRC Improved Data about Children, in Invernizzi, A. and Williams, J. The Human Rights of Children: From Visions to Implementation, Farnham: Ashgate, pp.133-158.

Gray, A. and Birrell, D. (2012). Coalition Government in Northern Ireland: Social Policy and the Lowest Common Denominator Thesis. Social Policy and Society,11, pp.1525 doi:10.1017/S1474746411000376

Greco, V. \& Sloper, P. (2004) Care coordination and key worker schemes for disabled children: results of a UK wide survey. Child: Care, Health and Development , 30 13-20.

Green Party Northern Ireland (2012) Proposals for a Private Member's Bill on a Statutory Duty to Co-operate, http://www.greenpartyni.org/ Accessed 5 December 2012.

Hudson, B. (2005) User Outcomes and Children's Services Reform: Ambiguity and Conflict in the Policy Implementation Process, Social Policy and Society, 5(2), 227-236.

Kaehne, A. and Beyer, S. (2009) Transition partnerships: the views of education professionals and staff in support services for young people with learning disabilities, British Journal of Special Education, 36(2) 112-119.

Lundy, L., Kilkelly, U., Byrne, B. and Kang, J. (2012) The UN Convention on the Rights of the Child: a study of legal implementation in twelve countries, London: UNICEF UK. 
Lundy, L. (2006) Mainstreaming Children's Rights in, to and through Education in a Society Emerging from Conflict, International Journal of Children's Rights, 14, pp.339362.

Northern Ireland Office (2009) A Bill of Rights for Northern Ireland: Next Steps. Belfast: Northern Ireland Office.

Office of the First and deputy First Minister (2006) A Ten Year Strategy for Children and Young People in Northern Ireland 2006-2016, Belfast: OFMDFM.

Office of the First and deputy First Minister (2009) Play and Leisure Policy, Belfast: OFMDM.

Scottish Government (2009) Do the Right Thing, Edinburgh: Scottish Government.

Sinclair, R. (2004) Participation in Practice: Making it Meaningful, Effective and Sustainable, Children and Society, 18, 106-118.

Tisdall, K. (2008) Is the Honeymoon Over? Children and Young People's Participation in Public Decision-Making, International Journal of Children's Rights, 16, 419-429.

Tisdall, K. and Davis, J. (2004) Making a Difference? Bringing children and young people's views into policymaking, Children and Society, 18(2), pp.131-142

United Nations (2009), Committee on the Rights of the Child, General Comment No. 12, (2009): The Right of the Child to be Heard, Geneva: United Nations. 
Reconciling Children's Policy and Children's Rights

United Nations (2008), Committee on the Rights of the Child, Concluding Observations to the United Kingdom of Great Britain and Northern Ireland, Geneva: United Nations.

United Nations (2005), Committee on the Rights of the Child, General Comment No. 7 (2005): Implementing Child Rights in Early Childhood, Geneva: United Nations.

United Nations (2003), Committee on the Rights of the Child, General Comment No. 5, General Measures of Implementation for the Convention on the Rights of the Child, Geneva: United Nations.

Welsh Assembly Government (2009) Getting it Right: a five year rolling Action Plan for Wales, Wales: Crown Copyright. 